\title{
Calling signals in sympatric species of the far-eastern Apbrophora (Homoptera: Auchenorrhyncha: Aphrophoridae): regularities of communication channel segregation
}

\section{Призывные сигналы дальневосточных симпатрических видов Apbropbora (Homoptera: Auchenorrhyncha: Aphrophoridae): закономерности разделения каналов связи}

\author{
D.Yu. Tishechkin \\ A.Ю. Тишечкин
}

Department of Entomology, Faculty of Biology, M.V. Lomonosov Moscow State University, Vorobyevy Gory, Moscow 119991, Russia. E-mail: macropsis@yandex.ru

Кафедра энтомологии Биологического факультета Московского государственного университета имени М.В. Ломоносова, Воробьевы Горы, Москва 119991, Россия.

KEY WORDS: spittle bugs, Aphrophoridae, Aphrophora, calling signals, vibrational communication, signal recognition.

КЛЮЧЕВЫЕ СЛОВА: пенницы, Aphrophoridae, Aphrophora, призывные сигналы, вибрационная коммуникация, распознавание сигналов.

ABSTRACT. Comparative investigation of male calling signals of six sympatric spittle bug species from the genus Aphrophora was conducted. In different species signals consist of either prolonged single or short repeated phrases. Within each group species differ from each other both in temporal pattern of rhythmic elements and in their duration and repetition period, sometimes quantitative differences being more reliable than qualitative ones. Similar regularities were described earlier in sympatric species of grasshoppers of the subfamily Gomphocerinae. Apparently, both in spittle bugs and in grasshoppers conspecific signal recognition is based primarily on the analysis of repetition period and duration of rhythmic elements, whereas fine interspecific differences in their inner structure are of little if any importance for this process.

РЕЗЮМЕ. Проведено сравнительное исследование призывных сигналов самцов шести симпатрических видов пенниц из рода Aphrophora. У разных видов сигналы могут состоять из продолжительных одиночных или коротких повторяющихся фраз. В пределах каждой группы виды различаются как по временнуй структуре ритмических элементов, так и по их длительности и периоду повторения, причем в ряде случаев количественные различия оказываются более надежными, чем качественные. Аналогичные закономерности ранее были описаны у симпатрических видов саранчовых подсемейства Gomphocerinae. Вероятно, как у пенниц, так и у саранчовых распознавание конспецифических сигналов происходит преимущественно по пе- риоду повторения и длительности ритмических элементов, в то время как небольшие межвидовые различия в их внутренней структуре не играют в этом процессе существенной роли.

\section{Introduction}

In every insect community acoustic signals (songs) of different species having the same seasonality and singing at the same time of a day necessarily differ from each other in at least one physical parameter. If the signal structure is more or less simple, the signals usually can be classified in several groups according to the general scheme of their temporal pattern. Within each group interspecific differences for the most part are quantitative in character. In other words, different species belonging to the same group usually differ from each other only in duration or/and repetition period of the components of the song. Grasshoppers and crickets (Orthoptera) can be cited as an example: several classifications of their signal types were provided both for all representatives of the order [Ragge \& Reynolds, 1998] and for individual smaller taxa [Bukhvalova, 2006; Tishechkin \& Bukhvalova, 2010]. Similar situation is observed in the jumping plant-lice (Homoptera: Psyllinea). For instance, vibrational calling signals of about 20 Craspedolepta s. 1. species (Psyllinea: Aphalaridae) can be subdivided in three main types, the signals of different species within each type differing from each other mainly in quantitative parameters [Tishechkin, 2007a and unpublished data]. 
At first glance it would seem that in small Auchenorrhyncha (Homoptera) situation is quite different. Timbal organs of these insects allow producing most elaborate and diverse signals, consisting of various complex elements. In leafhoppers, even the songs of closely related species sometimes have nothing in common with each other in temporal pattern. Cryptic species of the genus Macropsis Lewis, 1834 (Figs 1-7) and three species from the Aphrodes bicinctus (Schrank, 1776) species group (Figs 8-10) (Homoptera: Cicadellidae) provide good illustrations.

1

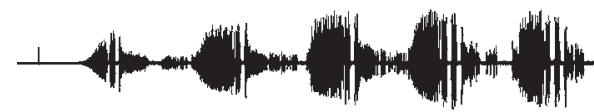

M. hinganensis Tish.

2

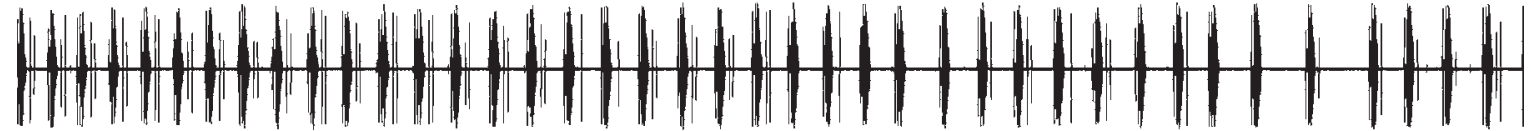

\section{M. leporina Tish.}

3

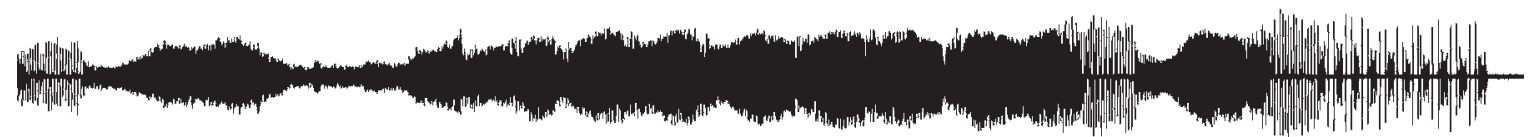

M. microcera Vilb.

4

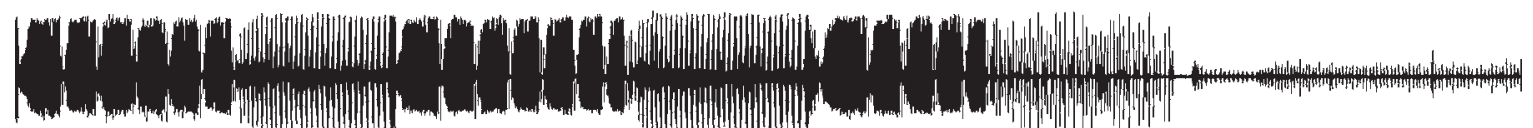

\section{M. multa Tish.}

5

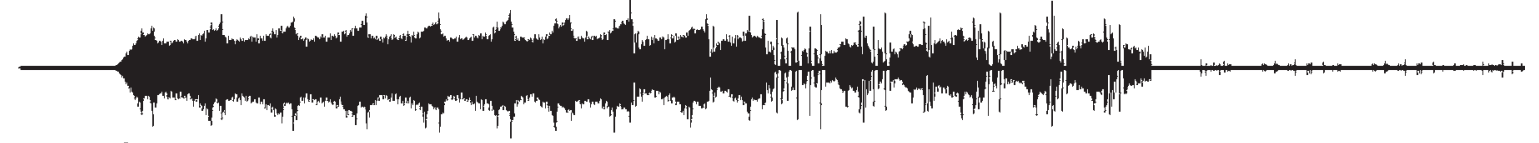

M. daurica Tish.

6

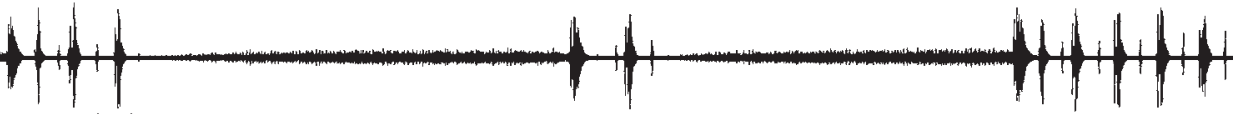

\section{M. ochotonaria Tish.}

7

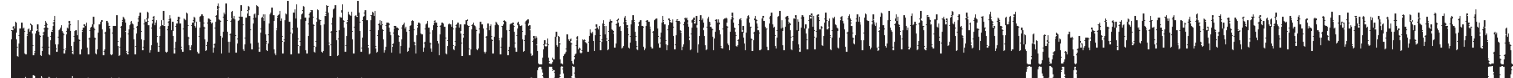

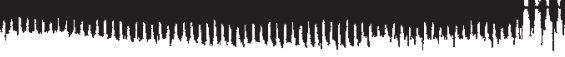

M. notata Proh.

8

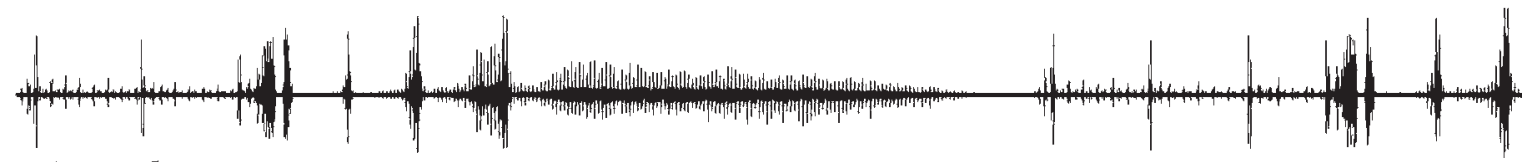

A. makarovi Zachv.

9

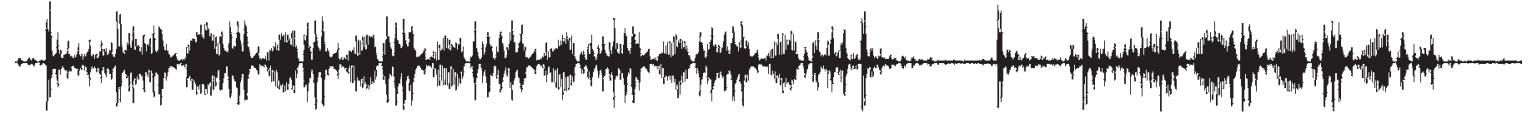

A. centrorossicus Zachv.

10

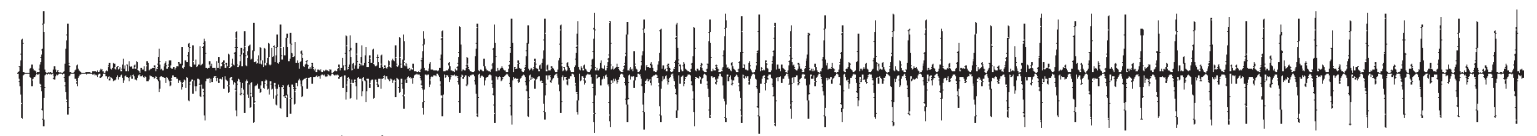

A. bicinctus Schrk.

Figs 1-10. Oscillograms of calling signals of closely related species of leafhoppers: 1-7 - cryptic species of the genus Macropsis, 8 10 - representatives of Aphrodes bicinctus species group.

Рис. 1-10. Осциллограммы сигналов близких видов цикадок: 1-7 - криптические виды рода Macropsis, $8-10$ — представители группы Aphrodes bicinctus. 
However, as new data on signals of small Auchenorrhyncha become available, more and more examples of similarity of signal temporal pattern in different species are revealed. For instance, it was found that the songs of the most part of palaearctic Fulgoroidea (Homoptera) are rather uniform and consist of simple trains of pulses [Tishechkin, 2003, 2008]. The only exceptions are the families Caliscelidae and Delphacidae, still in the latter one examples of similarity of signal temporal pattern can be found quite often [Tishechkin, 2008]. Paralimnini (Homoptera: Cicadellidae: Deltocephalinae) provide another example of this kind. Calling signals in different representatives of the tribe sometimes are almost indistinguishable and communication channel segregation in such cases is achieved by either allopatry or differences in host or habitat preferences [Tishechkin, 2007b, 2010].

In Cercopoidea (Homoptera: Auchenorrhyncha) vibrational signals in different species sometimes are also quite similar. Thus, in the spittle bugs (Aphrophoridae) temporal pattern of calling songs within each tribe as a rule have the same general scheme [Tishechkin, 2003]. On the territory of Russia this family is most diverse in the southern regions of the Russian Far East, where more than ten species sometimes can be found in the same locality. Moreover, Aphrophoridae usually have wide host preferences. Consequently, different species inhabiting the same biotope can perceive vibrational signals of each other.

The aim of the present study is a comparative investigation of calling signals of the far-eastern species of Aphrophora (Homoptera: Aphrophoridae) and revealing the principles of communication channel segregation in sympatric species of the genus.

\section{Material and methods}

Vibrational signals were registered by means of piezo-electric crystal gramophone cartridge connected to the microphone input of cassette recorder "Elektronika-302-1" (recordings made in 2002) or minidisk recorder Sony Walkman MZ-NH900 (recordings made in 2010) via the custom-made matching amplifier. In both cases manual mode of recording level control was used. Recordings were made either in a tent or under laboratory conditions immediately after collecting the insects.

Recordings of signals of five species, namely, $A$. pectoralis Matsumura, $1903(=$ A. costalis Matsumura 1903), A. obliqua Uhler, 1896, A. major Uhler, 1896, A. intermedia Uhler, 1896 and A. straminea Kato, 1932 were made in "Kedrovaya Pad" " (= "Cedar Valley") Nature Reserve, Khasan District, Maritime Province during the period from 11 to 22 August, 2010. The insects were collected in the buffer zone on the southeastern boundary of the Reserve on the meadows dominated by Lespedeza bicolor Turcz. (Fabaceae), Artemisia spp. (Asteraceae) and several species of high grasses (Poaceae), including Miscanthus sp. A. alni (Fallén, 1805) was also found here, but in the present paper we use signal recordings of this species made in July 2002 in the environs of Barabash-Levada Village (Pogranichny District of the Maritime Province) and on the bank of Khanka Lake 3-4 km north from Novokachalinsk Village (Khankaiskiy District of the Maritime Province). All recordings both in 2002 and in 2010 were made at the temperatures $24-27^{\circ} \mathrm{C}$.

True enough, certain species of Aphrophora demonstrate somewhat different host and habitat preferences. E.g. A. intermedia and A. alni were usually collected on shrubs and grass vegetation on the edge of the forest, whereas $A$. pectoralis as a rule dwells on willows, etc. These preferences are not very rigid, however. Quite often all species studied were found in the same biotope and thus are sympatric. For this reason investigation of communication channel segregation between the species listed above seems to be quite correct.

\section{Results and discussion}

Calling signals of Aphrophora consist of phrases (Figs 11-14), which are obviously homologous in different species, but have various duration and degree of complexity. In certain species individual phrases last for several seconds and follow each other with very long irregular intervals (Figs 11-12), whereas in other ones the songs consist of short and regularly repeated phrases (Figs 13-14). Typically each phrase consists of syllables separated by gaps (Figs 15-17); in the signals with most elaborate pattern each syllable, in turn also consists of discrete elements, so-called pulses (Fig. 19). If the gaps within syllables are reduced, syllable inner structure becomes more or less uniform and individual pulses merge into one fragment referred to as a syllable without distinct gaps (Fig. 20). Occasionally the gaps between syllables are also reduced and the inner structure of a phrase becomes indistinct (Fig. 18). As a result, we have the following classification of signal types. All signals are subdivided in two main groups: prolonged single phrases and short regularly repeated ones. Within each group there are two possible groups of the second order, namely, phrases with gaps and phrases without gaps. Phrases with gaps can consist either of syllables with gaps or of syllables without gaps; thus the groups of the third order are obtained.

As a consequence, the signals of the studied species of Aphrophora can be arranged as follows:

Prolonged single phrases (Figs 21-24)

Phrases without gaps - absent in our material

Phrases with gaps (Figs 29-31)

Syllables without gaps (Fig. 29): A. major Syllables with gaps (Figs 30-31): A. obliqua, A. pectoralis

Short regularly repeated phrases (Figs 25-28)

Phrases without gaps (Fig. 32): A. intermedia

Phrases with gaps (Figs 33-34)

Syllables without gaps (Fig. 33): A. straminea Syllables with gaps (Fig. 34): A. alni

Quantitative parameters of the signals of all species studied are given in the Table. 


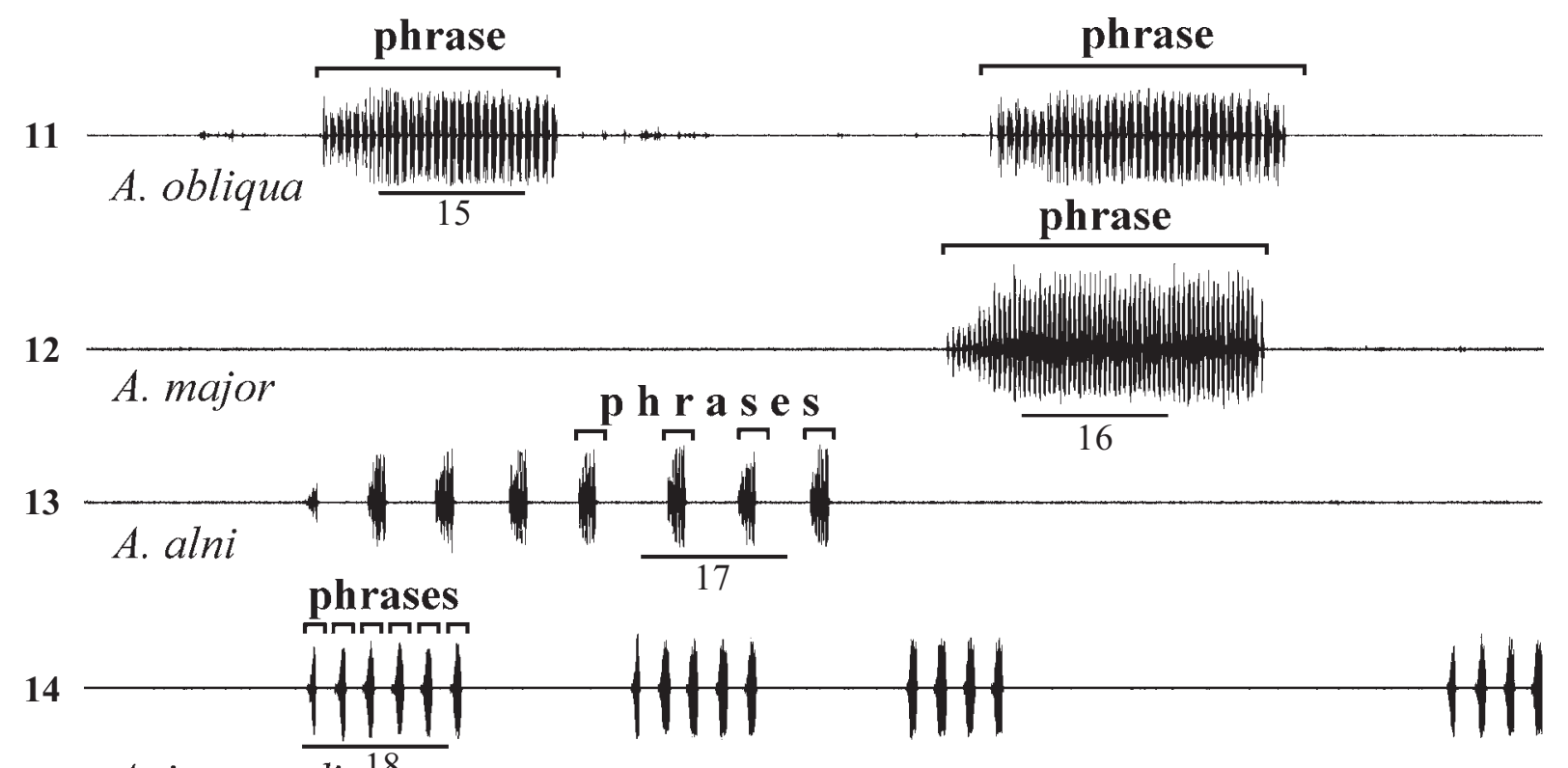

\section{A. intermedia ${ }^{18}$}

15

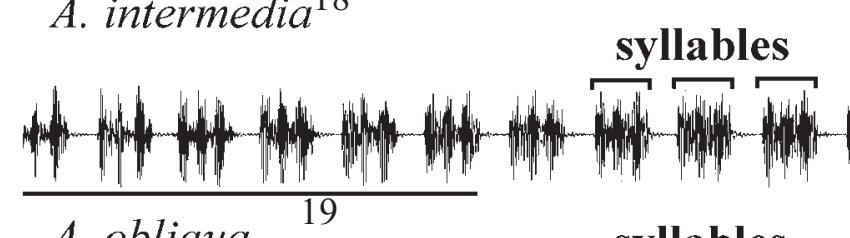

\section{A. obliqua}

16

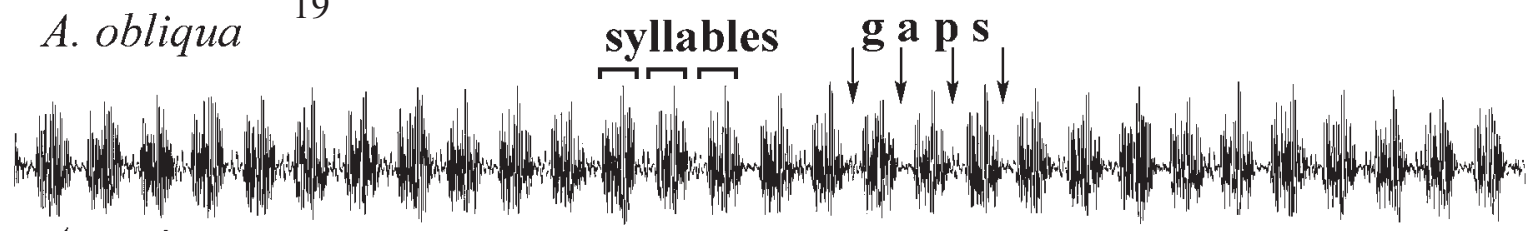

A. major

20

\section{syllables}

17

\section{A. alni}
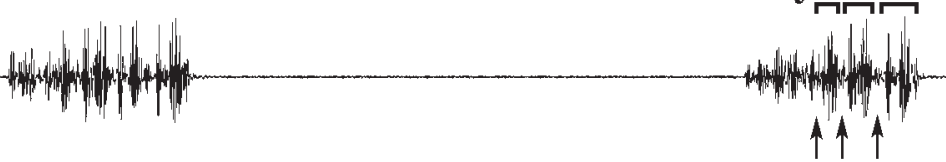

gaps

18

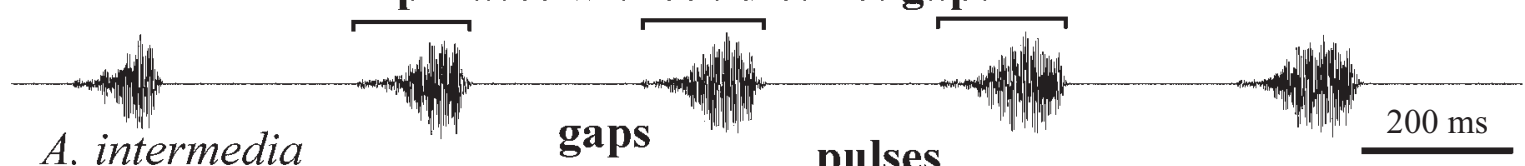

19

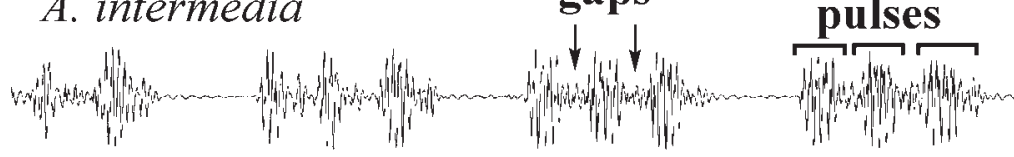

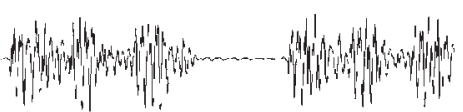

A. obliqua

\section{syllables without distinct gaps}

20

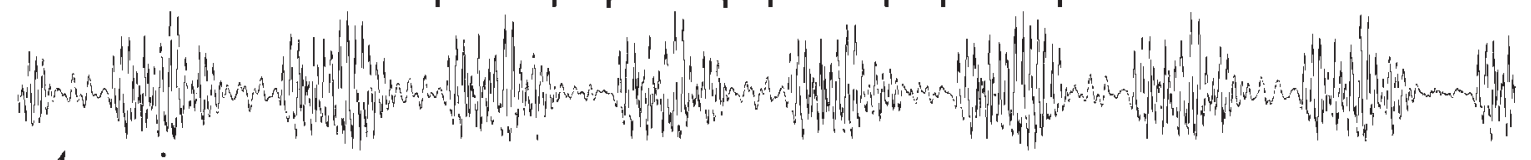

A. major

$100 \mathrm{~ms}$

Figs 11-20. Oscillograms of calling signals of the representatives of the genus Aphrophora illustrating terminology used in the paper. Faster oscillograms of the parts of signals indicated as " $15-20$ " are given under the same numbers.

Рис. 11-20. Осциллограммы призывных сигналов представителей рода Aphrophora, иллюстрирующие используемую в статье терминологию. Фрагменты сигналов, помеченные цифрами “15-20", представлены при большей скорости развёртки на осциллограммах под соответствующими номерами. 


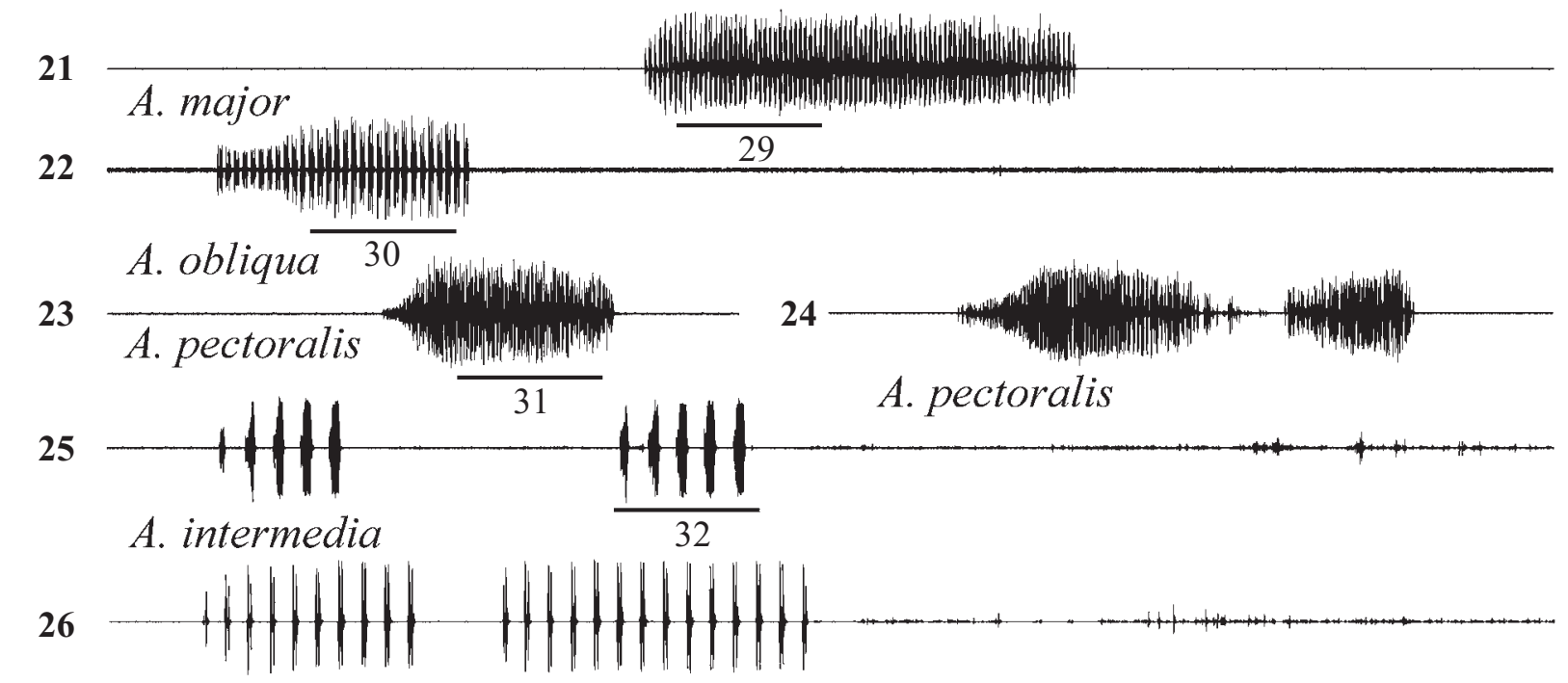

A. straminea

27

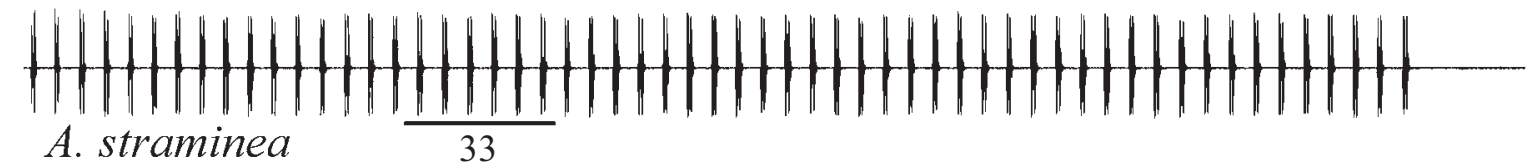

28

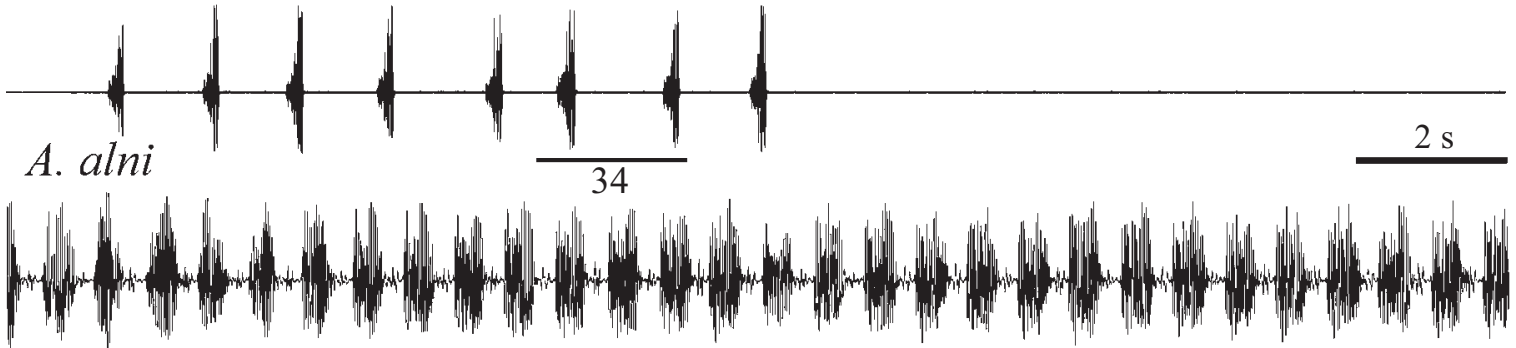

A. major

30

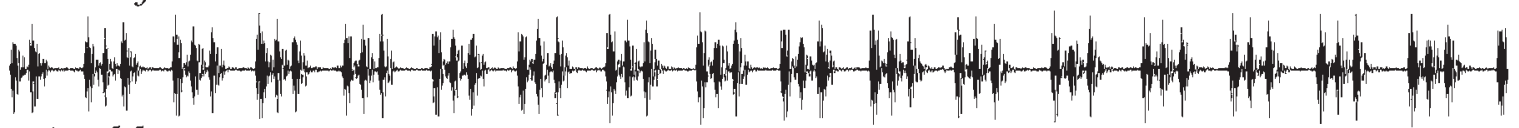

A. obliqua

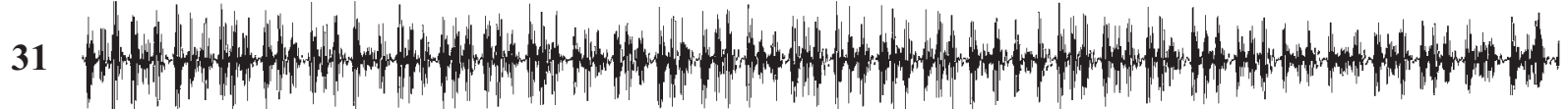

A. pectoralis

32

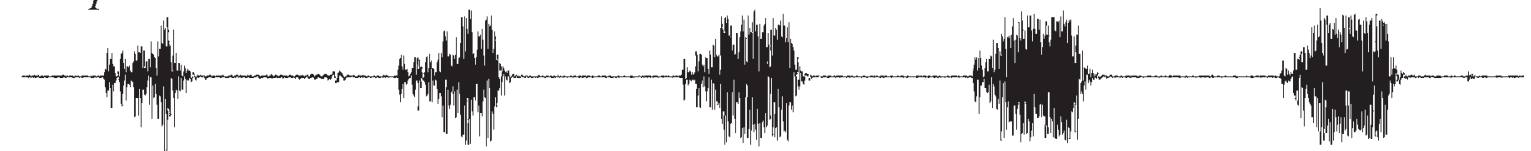

A. intermedia

33
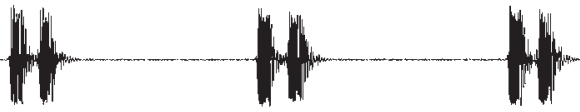

win
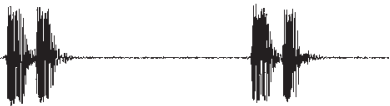

\section{$34 \frac{\text { A. straminea }}{\text { A. alni }}$}

$200 \mathrm{~ms}$

Figs 21-34. Oscillograms of calling signals of the species of the genus Aphrophora: $23-24$ - different signals of the same male of A. pectoralis, 26-27 - same, A. straminea. Faster oscillograms of the parts of signals indicated as "29-34" are given under the same numbers.

Рис. 21-34. Осциллограммы призывных сигналов видов рода Aphrophora: 23-24 - разные сигналы одного самца A. pectoralis, 26-27 - то же, A. straminea. Фрагменты сигналов, помеченные цифрами “29-34”, представлены при большей скорости развёртки на осциллограммах под соответствующими номерами. 
Table. Temporal parameters of calling signals of the species of Aphrophora. Таблица. Временные параметры призывных сигналов видов рода Aphrophora.

\begin{tabular}{|c|c|c|c|c|}
\hline Species & $\begin{array}{c}\text { Phrase } \\
\text { duration, ms }\end{array}$ & $\begin{array}{l}\text { Phrase repetition period, } \\
\mathrm{ms}\end{array}$ & $\begin{array}{l}\text { Syllable repetition } \\
\text { period, ms }\end{array}$ & Gaps in syllable \\
\hline A. pectoralis & $2500-4500$ & $\begin{array}{l}\text { Single or irregularly } \\
\text { repeated phrases }\end{array}$ & $50-71$ & present \\
\hline A. obliqua & $2300-4000$ & -"- & $104-126$ & present \\
\hline A. major & $4300-6000$ & -"- & $64-74$ & absent \\
\hline A. alni & $200-250$ & $750-1500$ & $34-53$ & present \\
\hline A. intermedia & $125-202$ & $359-428$ & \multicolumn{2}{|c|}{ phrases without gaps } \\
\hline A. straminea & $67-118$ & $291-360$ & $33-40$ & absent \\
\hline
\end{tabular}

As can be seen from the data presented, within the first group (prolonged single phrases) A. major differs from two other species in phrase duration. Theoretically, this character is sufficient to provide discrimination between this species and two other ones. However, $A$. major in addition differs from $A$. pectoralis and $A$. obliqua in syllable structure (syllables without distinct gaps, Fig. 29) and from the latter species also in syllable repetition period (Table). Evidently, in the signals of this type duration of a phrase alone cannot serve as a reliable species-specific character, since sometimes it varies greatly even within the song of the same specimen (Figs 23-24).

A. pectoralis and A. obliqua are most similar to each other in the song structure and fall into the same group of the 3rd order. Their calling signals have the same phrase duration and syllable pattern (syllables with gaps, Figs 30 and 31), but are widely different in a quantitative character, i.e. in syllable repetition period (Table).

Within the second group (short regularly repeated phrases) every species formally differs from two other ones in general appearance of phrases (see classification above and Figs 32-34). Besides, the ranges of both duration and repetition period of phrases in these species overlap only in extreme values if ever (Table). Duration of a phrase sequences is very variable (Figs 26-27) and therefore quite often has the same values in different species.

In $A$. alni and $A$. straminea producing phrases with gaps (Figs 33-34) syllable repetition period is identical. Also, in the phrases of $A$. intermedia irregular gaps occasionally occur (Fig. 32, first two phrases from the beginning of the signal), whereas in the signals of $A$. aln $i$ the gaps between initial syllables in a phrase as a rule are obscure (Fig. 34). It is reasonable to assume that the differences in the inner structure of the phrases are not reliable enough for acoustic distinction between different species of the second group.

By contrast, differences in phrase duration and repetition period are quite distinct (Table). Apparently, these are precisely the characters, which provide conspecific signal recognition. In general appearance, i.e. on the oscillograms at a low speed the signals of $A$. intermedia, $A$. alni and $A$. straminea differ from each other only in quantitative parameters (Figs 25-28).
Based on these data, acoustic characters most promising in taxonomy of Aphrophora for discrimination between closely related species could be revealed. Evidently, calling songs of two good species must differ from each other either in general structure of a signal (single or repeated phrases) or in repetition period of its components (phrases or syllables). As for the temporal pattern of syllables, it is the most reliable character for distinguishing between the songs of $A$. major and $A$. pectoralis; on the other hand, in three species producing short regularly repeated phrases differences in syllable and phrase temporal structure obviously are of little if any significance.

Thus, quantitative differences between the songs of sympatric species of Aphrophora quite often are no less important for conspecific signal recognition than the shape of phrases and syllables. In this respect spittle bugs are similar to grasshoppers of the subfamily Gomphocerinae (Orthoptera: Acrididae) [Tishechkin \& Bukhvalova, 2010] and demonstrate the same regularities of communication channel segregation between the species inhabiting the same biotope.

The signals of Gomphocerinae also consist either of prolonged single fragments referred to as echemes in the works on the sounds of Orthoptera or of short regularly repeated ones forming so-called echeme-sequences. Each group is subdivided in several subgroups with different general schemes of syllable pattern. Within each subgroup the songs of sympatric species, whether different or indistinguishable in syllable structure, necessarily differ from each other in syllable repetition period [Tishechkin \& Bukhvalova, 2010].

To cite one example, the songs of Glyptobothrus maritimus (Mistshenko, 1951), Chorthippus macrocerus (Fischer-Waldheim, 1846), Ch. vagans (Eversmann, 1848 ) and Omocestus petraeus (Brisout, 1855) belong to the same subgroup and are single prolonged echemes consisting of syllables with gaps (Figs 35-38). Inner temporal pattern of syllables in four species has minor but distinct differences (Figs 39-42). In G. maritimus, $C h$. macrocerus and $O$. petraeus the ranges of syllable repetition period overlap only in extreme values (104$192,170-335$ and 306-520 ms respectively at the temperature $27-30^{\circ} \mathrm{C}$ ), but the songs of $C h$. macrocerus and Ch. vagans are indistinguishable in this parameter (175$315 \mathrm{~ms}$ in the latter species). In the steppes of European 


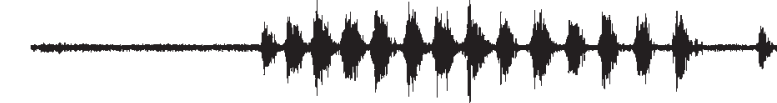

36

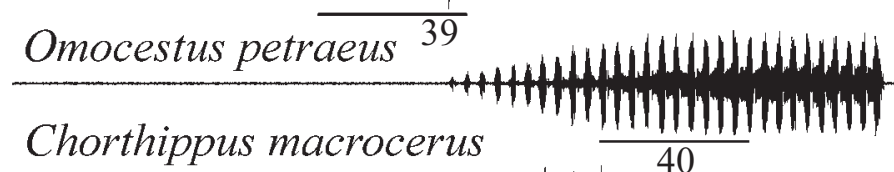

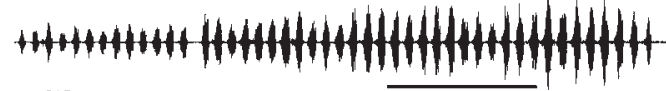

Ch. vagans

38

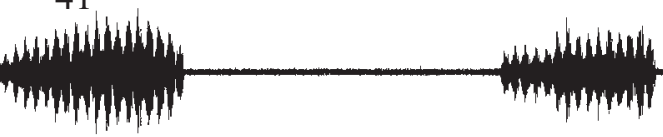

Glyptobothrus maritimus 42

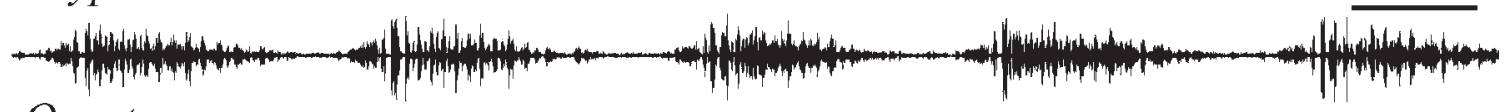

O. petraeus

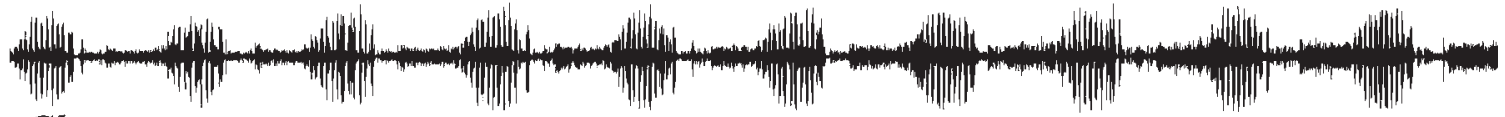

Ch. macrocerus

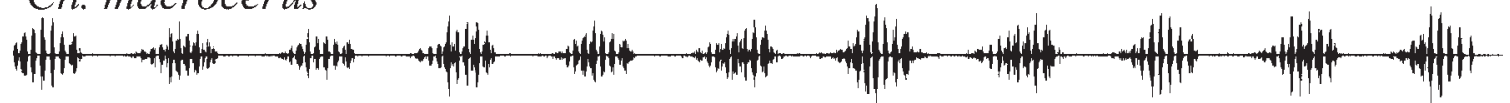

Ch. vagans

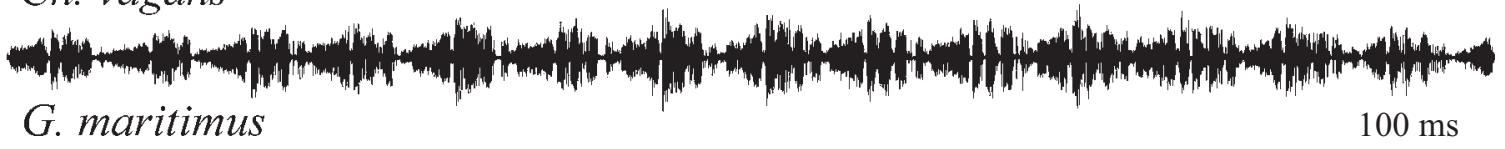

Figs 35-42. Oscillograms of calling signals of grasshoppers of the subfamily Gomphocerinae. Faster oscillograms of the parts of signals indicated as "39-42" are given under the same numbers.

Рис. 35-42. Осциллограммы призывных сигналов саранчовых подсемейства Gomphocerinae. Фрагменты сигналов, помеченные цифрами “39-42”, представлены при большей скорости развёртки на осциллограммах под соответствующими номерами.

Russia these species quite often inhabit the same biotopes in various combinations, with one exception. Ch. vagans and Ch. macrocerus were never found together, but replaced each other in different habitats. This suggests that in Gomphocerinae, as in Aphrophora, these are quantitative characters, which provide acoustic segregation between sympatric species, whereas the details of syllable structure can play only small if any role in this process.

Similarity in the regularities of communication channel segregation in non-related taxa, namely, Acrididae (Orthoptera) and Aphrophoridae (Homoptera: Auchenorrhyncha) supports the hypothesis for existence of a unified mechanism of conspecific signal recognition in insect nervous system. Apparently, this mechanism is based primarily on the analysis of repetition period and duration of rhythmic elements of the song, whereas fine interspecific differences in the structure of these elements, i.e. of phrases or syllables usually are of little if any importance.

ACKNOWLEDGEMENTS. I am greatly indebted to Dr. Mikhail Krechmar ("Kedrovaya Pad" "State Nature Reserve) for his kind permission to conduct my investigations on the territory of the Reserve and for his invaluable help during my visit to "Kedrovaya Pad' ". The study was supported by Russian Foundation for Basic Research (No. 10-04-00275a) and a grant of a State Program "Development of Scientific Potential of Higher School" (project No. RNP.2.1.1.3267 "Ecosystem Functions, Mechanisms of Reproduction and Evolution of Biological Diversity").

\section{References}

Ragge D.R. \& Reynolds W.J. 1998. The songs of the grasshoppers and crickets of Western Europe. Harley Books, England (in association with The Natural History Museum, London). 591 pp.

Bukhvalova M.A. 2006. Partitioning of acoustic transmission channels in grasshopper communities // Insect Sounds and Communication. Physiology, Behaviour, Ecology and Evolution. Eds.: S. Drosopoulos, M.F. Claridge. CRC Press, Taylor and Francis Group, Boca Raton, London, New York. P.199-205.

Tishechkin D.Yu. 2003. Vibrational communication in Cercopoidea and Fulgoroidea (Homoptera: Cicadina) with notes on classification of higher taxa// Russian Entomol. J. Vol.12. No.2. P.127-181.

Tishechkin D.Yu. 2007a. Potentialities of using bioacoustic characters in taxonomy of jumping plant lice: an example of the genus Craspedolepta (Homoptera, Psyllinea, Aphalaridae) with description of a new species from Transbaikalia // Zoologicheskiy Zhurnal. Vol. 86. No.6. P. 691-700 [in Russian with English summary]. 
Tishechkin D.Yu. 2007b. Similar calling signals in different species of leafhoppers (Homoptera: Cicadellidae): an example of Paralimnini // Russian Entomol. J. Vol.16. No.3. P.265-272.

Tishechkin D.Yu. 2008. On the similarity of temporal pattern of vibrational calling signals in different species of Fulgoroidea (Homoptera: Auchenorrhyncha) // Russian Entomol. J. Vol.17. No.4. P.343-351.
Tishechkin D.Yu. 2010. Vibrational signals in sympatric species of leafhoppers: Paralimnini (Homoptera: Cicadellidae: Deltocephalinae) in the valley of Irkut River, Eastern Siberia - a case study // Russian Entomol. J. Vol.18 (for 2009). No.4. P.265-272.

Tishechkin D.Yu. \& Bukhvalova M.A. 2010. Acoustic communication in grasshopper communities (Orthoptera: Acrididae: Gomphocerinae): segregation of acoustic niches // Russian Entomol. J. Vol.18 (for 2009). No.3. P.165-188. 